\title{
Comparative study of fluoride conversion coatings formed on biodegradable powder metallurgy Mg: The effect of chlorides at physiological level
}

\author{
M.D. Pereda ${ }^{\mathrm{a}, \mathrm{b}}$, C. Alonso ${ }^{\mathrm{c}}$, M. Gamero ${ }^{\mathrm{c}}$, J.A. del Valle ${ }^{\mathrm{d}}$, M. Fernández Lorenzo de Mele ${ }^{\mathrm{a}, \mathrm{b}, *}$ \\ a Instituto de Investigaciones Fisicoquímicas Teóricas y Aplicadas (INIFTA, CCT La Plata-CONICET), Facultad de Ciencias Exactas, Universidad Nacional de La Plata, \\ Casilla de Correo 16, Sucursal 4, (1900) La Plata, Argentina \\ b Facultad de Ingeniería, Universidad Nacional de La Plata, Calle 47 y 1, (1900) La Plata, Argentina \\ c Departamento de Química Física Aplicada, Universidad Autónoma de Madrid, 28049 Madrid, Spain \\ d Centro Nacional de Investigaciones Metalúrgicas (CENIM), Consejo Superior de Investigaciones Científicas (CSIC), 28040 Madrid, Spain
}

\section{A R T I C L E I N F O}

\section{Article history:}

Received 3 June 2010

Received in revised form 17 November 2010

Accepted 26 January 2011

Available online 4 February 2011

\section{Keywords:}

Magnesium

Fluoride conversion coating

Chloride

Biodegradable

Powder metallurgy

Biomaterial

\begin{abstract}
A B S T R A C T
The development of a biodegradable metallic implant demands a precisely defined degradation profile and adequate mechanical properties. $\mathrm{Mg}$ has been proposed for this purpose but it has an excessively high corrosion rate and insufficient yield strength. In the present work pure $\mathrm{Mg}$ mechanically reinforced by a powder metallurgy $(\mathrm{Mg}(\mathrm{PM}))$ route and treated with $\mathrm{KF}$ was used. The effect of chlorides, at the physiological level, on four fluoride conversion coatings (F-CC) formed on $\mathrm{Mg}(\mathrm{PM})$ was evaluated comparatively. The behavior of $\mathrm{Mg}(\mathrm{PM})$ during fluoride treatments $(0.01 \mathrm{M}-0.3 \mathrm{M}$ fluoride-containing solutions) before and after the addition of chlorides $\left(8 \mathrm{~g} \mathrm{~L}^{-1} \mathrm{NaCl}\right)$ was investigated by conventional corrosion techniques and by scanning electrochemical microscopy (SECM) complemented with SEM observations and EDX analysis. Results showed that the composition and the microstructural characteristics of the F-CCs as well as their corrosion behavior change with KF concentration and immersion time. Treatments in the $0.01 \mathrm{M}-0.1 \mathrm{M} \mathrm{KF}$ range prove to be effective to protect $\mathrm{Mg}(\mathrm{PM})$ against corrosion in the absence of chlorides while higher $\mathrm{KF}$ solution concentration $(0.3 \mathrm{M})$ adversely affects the corrosion resistance of this metal. In the presence of chloride ions the F-CCs progressively lose their fluoride content and their corrosion resistance at a rate that depends on the treatment conditions. Such temporary corrosion protection is appropriate for biodegradable implants.
\end{abstract}

(c) 2011 Elsevier B.V. All rights reserved.

\section{Introduction}

Magnesium and its alloys are considered the lightest structural materials with potential applications in different areas such as automotive, aircraft, electronics and aerospace [1-4]. In the last few years they have also been proposed as promissory biodegradable biomaterials. These biomaterials have several advantages in relation to fixed implants, since they can avoid some of the harmful effects of non-degradable implants and prevent the second surgery necessary to remove the traditional implants. Additionally, their mechanical properties are closer to those of bone and they are able to stimulate growth of new bone tissue and reduce stress shielding [5-9]. Their degradation properties are also useful in the case of cardiovascular implants [10,11], particularly for preterm babies [12]. From the biological point of view, the use of pure $\mathrm{Mg}$ is more advisable than $\mathrm{Mg}$ alloys because it prevents the release of toxic ions.

However, there are negative issues that should be solved before using Mg-based materials. Pure magnesium typically has a yield

\footnotetext{
* Corresponding author at: INIFTA, Casilla de Correo 16, Sucursal 4, 1900 La Plata, Argentina. Tel.: +54221 4257430; fax: +54 2214254642 .

E-mail address: mmele@inifta.unlp.edu.ar (M. Fernández Lorenzo de Mele).
}

strength of $55 \mathrm{MPa}$, lower than natural bone (e.g. femur $\approx 110 \mathrm{MPa}$ ) and shows excessively high degradation rates in body fluids [13-20]. Powder metallurgical (PM) route was used to prepare $\mathrm{Mg} / \mathrm{HA}$ biocomposite with cytotoxicity and corrosion resistance dependent on the HA content $[21,22]$. PM route was also used to upgrade the mechanical properties of pure $\mathrm{Mg}$ [23-25]. $\mathrm{Mg}(\mathrm{PM})$ benefits from a large grain size refinement in comparison with cast magnesium, and the development of a considerable crystallographic texture and, additionally, the presence of the dispersion of magnesium oxide particles produces mechanical reinforcement. As a result of these microstructural improvements the material obtained in the present work has a $2 \%$ ductility, offset stress (at $0.2 \%$ strain) of $280 \mathrm{MPa}$ and a tensile stress of $320 \mathrm{MPa}$ close to values obtained in the widely used AZ31 magnesium alloy [24].

To improve the corrosion resistance of $\mathrm{Mg}(\mathrm{PM})$, among different inhibition treatments proposed [26,27], the treatment with KF solution seems to be promissory since it is low-cost, non-toxic simple and easily handled for biomedical applications. Besides, fluoridetreated biomaterials have shown lower cytotoxicity level and better biocompatibility than controls [28,29]. The effect of fluoride treatments on $\mathrm{Mg}$ alloys has been recently described [30]. The authors showed that the behavior of AZ91D Mg alloy is very complex when 
chlorides are also present in the aqueous solution. Since $\mathrm{Mg}$ is potentially useful as degradable implant and considering that chloride is very abundant in body fluids, this condition deserves a particular investigation in the case of $\mathrm{Mg}(\mathrm{PM})$.

The techniques so far used to study corrosion problems (potentiostatic and potentiodynamic polarization curves, transient currents, electrochemical impedance spectroscopy, etc.) give valuable surfaceaverage information on the system.

On the other hand, scanning electrochemical microscopy (SECM) is a powerful technique which can be applied to monitor both insulating and conducting surfaces [31]. This microelectrochemical technique consists in the movement of an ultramicroelectrode tip (UME) parallel to the surface of the sample inside an electrochemical cell. The UME can be positioned close to the interface with submicron precision and can probe the topography, reactivity or permeability of that interface with high spatial resolution $[32,33]$.

Due to the fact that some electrochemical mediators employed in SECM can interfere with the electrochemical reactions that take place in the corrosion process, it is necessary to use as electrochemical mediators species already present in the system under study. For example, the ionic species resulting from localized corrosion processes can be detected at the tip [34] and the local variations in the extent of metal corrosion can be measured [35]. It is also possible to use oxygen dissolved in the electrolyte as mediator, since it is an electroactive molecule. Thus, the need for the addition of a redox mediator is avoided $[35,36]$.

This technique has been applied to several corrosion problems, such as pitting corrosion [37,38], mapping of the surface conductivity of aluminum alloys [39], imaging of cathodic protection of aluminum [40], and recently to evaluate a Mg surface treated with alternating voltage [41]. In the present work we report a novel use of this electrochemical technique that involves monitoring changes in surface reactivity over time during passivating treatments.

The aim of this work was to evaluate the protective characteristics of different fluoride conversion coatings (F-CC) formed on $\mathrm{Mg}(\mathrm{PM})$ surfaces when they are in contact with chloride ions at the physiological levels in an attempt to contribute to the elucidation of the chloride-assisted F-CC degradation process without the interference of other ions. With this purpose the electrochemical behavior of $\mathrm{Mg}(\mathrm{PM})$ during fluoride treatments before and after the addition of chloride ions was investigated. Conventional corrosion techniques (open circuit potential measurements $\left(\mathrm{E}_{\mathrm{ocp}}\right)$, transient currents, and electrochemical impedance spectroscopy (EIS)) together with SECM were used.

\section{Materials and methods}

\subsection{Materials}

Magnesium powder (99.8\%, 325 mesh) was supplied by Alfa Aesar. The powders were cold-pressed and the resulting cylindrical compacts of $40 \mathrm{~mm}$ in diameter were extruded in the form of bars at $420^{\circ} \mathrm{C}$, employing an extrusion ratio of $16: 1$ [24,25].

Cylindrical samples ( $1 \mathrm{~cm}$ diameter) were cut from $\mathrm{Mg}(\mathrm{PM})$ bars. The lateral surfaces were covered by epoxy resin leaving a circular exposed area of $0.785 \mathrm{~cm}^{2}$. The samples were ground and dry polished with SiC papers of successively finer grit down to 1500 grit. Once polished, the samples were rinsed in ethanol and dried with nitrogen.

The sample surface appearance was carefully examined by optical microscopy before and after the experiments so as to check color and texture uniformity of the conversion coating. SEM observations were also made (EI Quanta 200 in high vacuum mode).

The equipment used for the characterization of magnesium samples was a Philips XL30 Scanning Electron Microscope, coupled to the EDX DE4i analyser. The phases present in the coating were determined by X-ray diffractometry (X'Pert PRO XRD, Panalytical).
2.2. Reagents, solutions and pretreatments of the samples for electrochemical measurements

All the solutions were prepared with ultrapure water by means of a Millipore Milli-Q system $\left(18.2 \mathrm{M} \Omega^{-1}\right)$. The compositions of the solutions employed in the experiments were: $0.01 \mathrm{M} \mathrm{KF}, 0.03 \mathrm{M} \mathrm{KF}$, $0.1 \mathrm{M} \mathrm{KF}, 0.3 \mathrm{M} \mathrm{KF}$ and $8 \mathrm{~g} \mathrm{~L}^{-1} \mathrm{NaCl}$. Analytical grade reagents were used in all cases.

Prior to some of the electrochemical experiments the $\mathrm{Mg}(\mathrm{PM})$ electrodes were immersed in $8 \mathrm{~g} \mathrm{~L}^{-1} \mathrm{NaCl}$ solutions for $1 \mathrm{~h}$ to induce surface attack (Mg(PM)SA).

Electrochemical measurements were performed after different treatments and under different experimental conditions in order to investigate the corrosion resistance of the $\mathrm{Mg}(\mathrm{PM})$ and $\mathrm{Mg}(\mathrm{PM}) \mathrm{SA}$ treated with KF solutions in the absence and in the presence of chloride ions: a) transient currents and SECM were recorded with $\mathrm{Mg}$ (PM)SA during the passivating treatments with KF solutions, b) EIS experiments were performed in $8 \mathrm{~g} \mathrm{~L}^{-1} \mathrm{NaCl}$ solution with $\mathrm{Mg}(\mathrm{PM})$ passivated with $0.01 \mathrm{M}, 0.03 \mathrm{M}, 0.1 \mathrm{M}$ and $0.3 \mathrm{M}$ KF solutions; and $\mathrm{c}$ ) transient currents and $\mathrm{E}_{\text {ocp }}$ with $\mathrm{Mg}(\mathrm{PM}) \mathrm{SA}$ were recorded in $0.1 \mathrm{M} \mathrm{KF}$ solution to which $\mathrm{NaCl}$ was added after different periods up to physiological level $\left(8 \mathrm{~g} \mathrm{~L}^{-1}\right)$.

\subsection{SECM characterization}

The surface topography was studied before and during fluoride conversion coating formation (F-CC) using a SECM (Sensolytics) equipped with a $10 \mu \mathrm{m}$ platinum tip (ultramicroelectrode, UME) as probe, $\mathrm{Ag} / \mathrm{AgCl} / \mathrm{KCl}$ reference electrode, and a platinum wire as counter electrode, all placed within a polytetrafluoroethene cell. $\mathrm{Mg}$ (PM)SA specimens were mounted horizontally facing upwards. Open circuit potential $\left(\mathrm{E}_{\mathrm{ocp}}\right.$ ) experiments were performed in $0.1 \mathrm{M} \mathrm{KF}$ solution as background electrolyte. The scan rate of the microscope tip over the specimen surface was $10 \mu \mathrm{m} \mathrm{s}^{-1}$ in unidirectional lines, with $5 \mu \mathrm{m}$ separation between line scans. The maps were generated with the tip located c.a. $10 \mu \mathrm{m}$ from the $\mathrm{Mg}(\mathrm{PM}) \mathrm{SA}$ surface.

In order to study the passivating action of fluoride ions on $\mathrm{Mg}(\mathrm{PM})$ samples they were previously corroded in $8 \mathrm{~g} \mathrm{~L}^{-1} \mathrm{NaCl}$ for $1 \mathrm{~h}(\mathrm{Mg}$ (PM)SA) before dipping into the SECM electrolytic cell with $0.1 \mathrm{M} \mathrm{KF}$ aerated solution (treatment (a)). The chemical activity was measured in a feedback mode using $\mathrm{O}_{2}$ dissolved in solution as electrochemical mediator. The oxygen related current was recorded directly by the SECM-tip set at $-0.70 \mathrm{~V}$. At this potential, $\mathrm{O}_{2}$ reduction occurs under diffusion control and the current magnitude at the microelectrode is dependent on the $\mathrm{O}_{2}$ concentration.

The UME was scanned over a $2000 \mu \mathrm{m} \times 600 \mu \mathrm{m}$ area of the sample. The localized differences in the concentration of oxygen lead to variations in the faradic current which passes through the tip.

\subsection{Transient currents and $E_{\text {ocp }}$ measurements}

An electrochemical cell with a three-electrode setup was used. A platinum wire (99.99\% purity) served as auxiliary electrode. All potentials are quoted with respect to the $\mathrm{Ag} / \mathrm{AgCl} / \mathrm{KCl}$ reference electrode. The exposed area of the working electrode $(\mathrm{Mg}(\mathrm{PM}) \mathrm{SA}$ disk) was $0.785 \mathrm{~cm}^{2}$ for all the experiments.

A TEQ-02 potentiostat was used for electrochemical measurements. Transient currents were recorded using $\mathrm{Mg}(\mathrm{PM}) \mathrm{SA}$ as working electrode at fixed potentials ( $\mathrm{E}_{\text {ocp }}+50 \mathrm{mV}$, vs. $\mathrm{Ag} / \mathrm{AgCl} / \mathrm{KCl}$ ) in $0.01 \mathrm{M}, 0.03 \mathrm{M}, 0.1 \mathrm{M}$ and $0.3 \mathrm{M}$ KF solutions (treatment (a)).

$\mathrm{E}_{\text {ocp }}$ and transient currents recorded at $\mathrm{E}_{\text {ocp }}+50 \mathrm{mV}, \mathrm{vs} . \mathrm{Ag} / \mathrm{AgCl} / \mathrm{KCl}$ with $\mathrm{Mg}(\mathrm{PM}) \mathrm{SA}$ in $0.1 \mathrm{M} \mathrm{KF}$ with $\mathrm{NaCl}$ additions up to physiological level, ( $\left.8 \mathrm{~g} \mathrm{~L}^{-1}\right)$ (treatment (c)) after different times ( $0.5 \mathrm{~min}$ and $1 \mathrm{~min}$ ) were also measured to analyze the effect of chloride ions on the protective characteristics of the film. 


\subsection{Electrochemical impedance spectroscopy measurements}

The EIS were performed with an Autolab PGSTAT 30 potentiostat from Eco-Chemie. The $\mathrm{Mg}(\mathrm{PM})$ samples were pre-treated in aereated $0.01 \mathrm{M}, 0.03 \mathrm{M}, 0.1 \mathrm{M} \mathrm{KF}$ and $0.3 \mathrm{M} \mathrm{KF}$ solutions for $1 \mathrm{~h}$. A sinusoidal potential modulation of $\pm 10 \mathrm{mV}$ amplitude in the $10^{5} \mathrm{~Hz}-10^{-2} \mathrm{~Hz}$ frequency range, spaced logarithmically (120 per 8 decades), was superimposed on the $\mathrm{E}_{\text {ocp }}$ of $\mathrm{F}^{-}$-coating $\mathrm{Mg}(\mathrm{PM})$ in $8 \mathrm{~g} \mathrm{~L}^{-1} \mathrm{NaCl}$.

A control assay for the electrodes without pre-treatment could not be included because of the high scattering of the results due to the unstable behavior of the $\mathrm{Mg}(\mathrm{PM}) \mathrm{SA}$ bare surface in $\mathrm{NaCl}$ solutions [42].

\section{Results}

\subsection{F-CC formation on corroded surfaces}

\subsubsection{Transient currents}

The change in the average activity of the electrode surface during KF treatments was followed by transient current measurements and was used to identify the more appropriate protective treatments. Prior to each electrochemical measurement, and in order to enhance the detection of the protective effect of $\mathrm{F}^{-}$ions on active surfaces, the $\mathrm{Mg}$ (PM) sample was immersed into $8 \mathrm{~g} \mathrm{~L}^{-1} \mathrm{NaCl}$ for $1 \mathrm{~h}$. The microscopic observation of $\mathrm{Mg}(\mathrm{PM})$ with surface attack $(\mathrm{Mg}(\mathrm{PM}) \mathrm{SA})$ (Fig. 1a and b) shows regions with and without localized attack and others
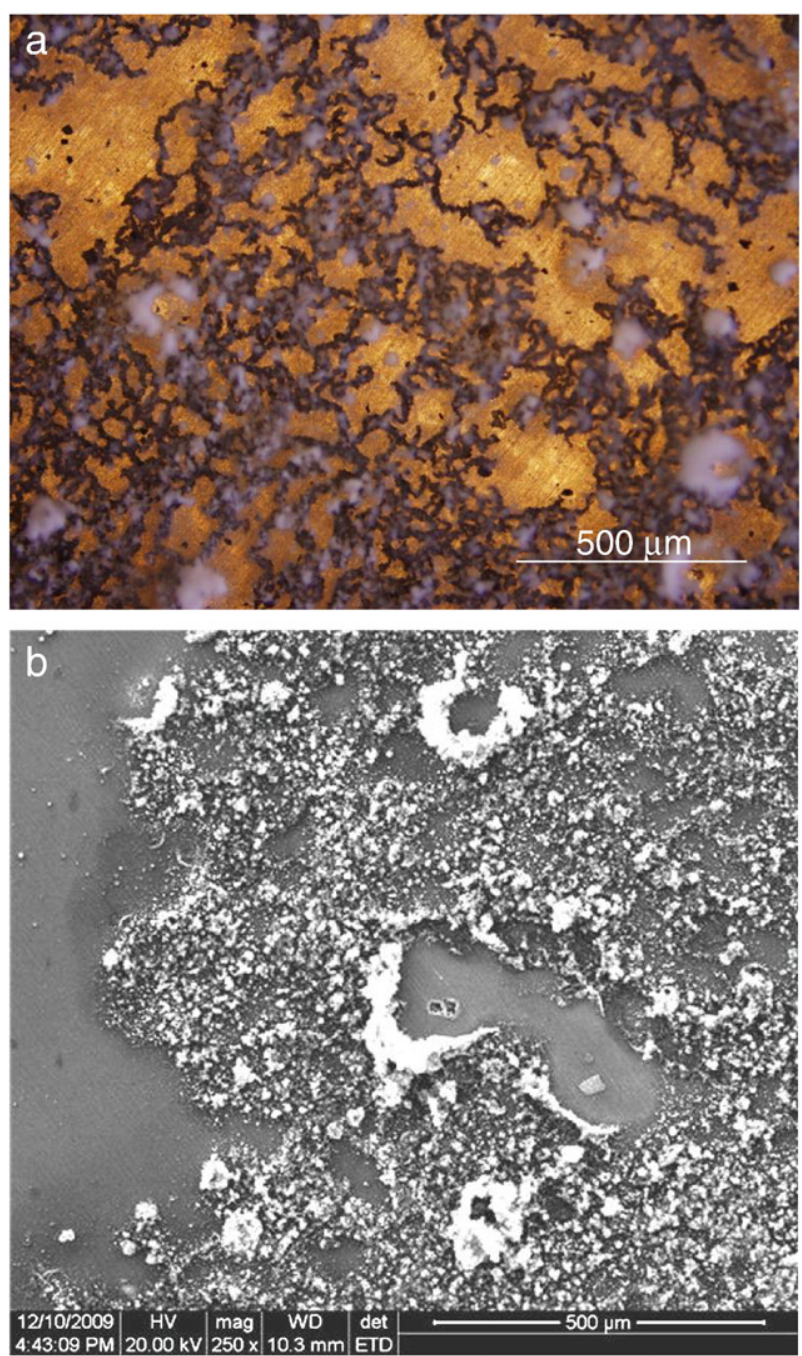

Fig. 1. (a) Optical microscope and (b) SEM images of the $\mathrm{Mg}(\mathrm{PM})$ after being immersed in $8 \mathrm{~g} \mathrm{~L}^{-1} \mathrm{NaCl}$ for $1 \mathrm{~h}(\mathrm{Mg}(\mathrm{PM}) \mathrm{SA})$. covered by corrosion products. After this pre-treatment the samples were immersed in KF of different concentrations to identify the best passivating process. Fig. 2 shows that the transient currents recorded at $50 \mathrm{mV}$ were more anodic than the instantaneous $\mathrm{E}_{\text {ocp. }}$. Initially, the best performance was depicted in $0.1 \mathrm{M}$ KF solutions, which showed the lower and more stable current values. In solutions with lower $\mathrm{F}^{-}$ concentrations ( $0.01 \mathrm{M}$ and $0.03 \mathrm{M} \mathrm{KF})$ the initial current values were high and very unstable. Interestingly, these current values decreased sharply and reached cathodic values after some seconds. Although $0.3 \mathrm{M} \mathrm{KF}$ assays showed low current values initially, these values increased later, revealing the adverse effect of high KF concentrations.

\subsubsection{SECM characterization}

The local current, related to the in situ conductivity was mapped by the SECM revealing the hill- or valley-like current fluxion in the vertical $\mathrm{Z}$ direction. Fig. 3 shows the surface scanning before and during the formation of the conversion coating in $0.1 \mathrm{M} \mathrm{KF}$ solution. The effect of $\mathrm{F}^{-}$during the immersion of the corroded sample in a $0.1 \mathrm{M}$ KF solution followed by this electrochemical imaging technique allows in situ mapping of the chemical reactivity of surfaces and visualization of spatially-confined variations in conductivity. When the tip moves over the areas covered by a hydroxide film, the tip current decreases, because the diffusion of $\mathrm{O}_{2}$ is physically hindering towards the probe (negative feedback, i.e. negative current decreases). However, when it moves over the active areas (localized corrosion micropits), the tip-sample distance increases, decreasing the $\mathrm{O}_{2}$ concentration that reaches the tip, causing the decrease of the reduction current. The successive curves plotted in the $\mathrm{X}-\mathrm{Z}$ plane represent the map of the active areas at each $X$ position while those of $\mathrm{Y}-\mathrm{Z}$ plane represent the change in the reactivity with time. Due the protective effect of the background electrolyte ( $0.1 \mathrm{M} \mathrm{KF})$ which gradually covers the active areas, lower variation in the current values was progressively detected during the successive scans, giving rise to c.a. constant current values at the end of the experiment, associated with the flat image of a passive surface.

Unfortunately, due to the formation of hydrogen bubbles, SECM measurements in the presence of chloride ions cannot be made.

\subsection{F-CC formation on non-corroded surfaces}

Fig. $4 \mathrm{a}-\mathrm{c}$ shows that after $1 \mathrm{~h}$ exposure in solutions of $0.01,0.03$ and $0.1 \mathrm{M} \mathrm{KF}$ a compact film is formed with some needle shape

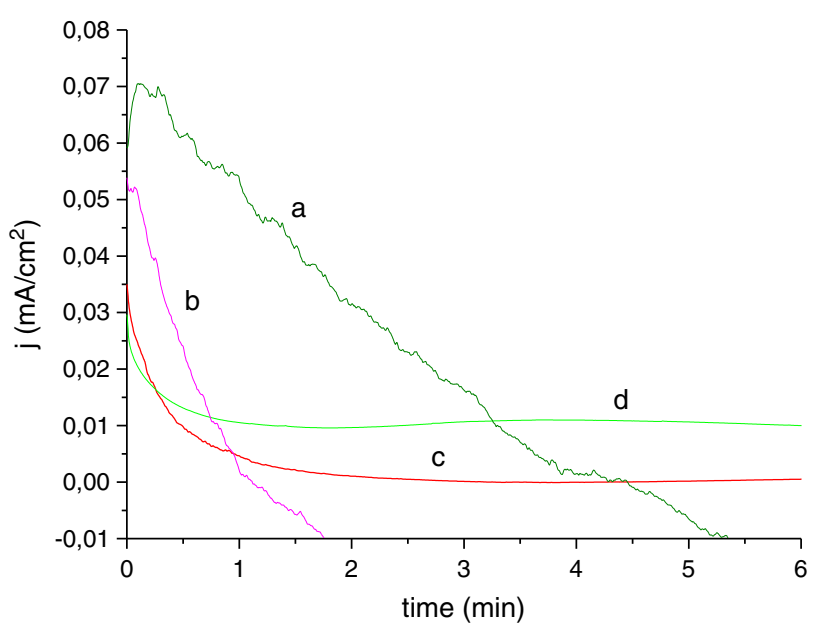

Fig. 2. Transient current corresponding to $\mathrm{Mg}(\mathrm{PM}) \mathrm{SA}$ recorded at $50 \mathrm{mV}$ more anodic than the open circuit potential in different KF solutions: (a) $0.01 \mathrm{M}$, (b) $0.03 \mathrm{M}$, (c) $0.1 \mathrm{M}$ and (d) $0.3 \mathrm{M}$. 


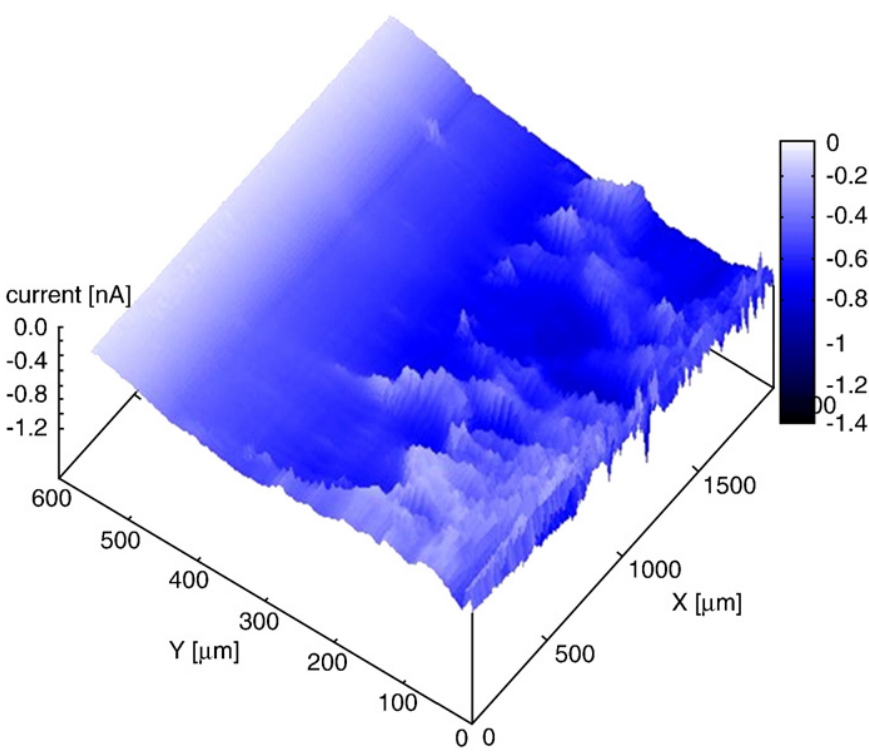

Fig. 3. $\mathrm{SECM}$ images of a $\mathrm{Mg}(\mathrm{PM}) \mathrm{SA}$ sample during $0.1 \mathrm{M} \mathrm{KF}$ treatment. Tip potential is $-0,70 \mathrm{~V}$.

crystals on the surface. EDX analysis showed that F-at.\% increases with time (from $7 \%(1 \mathrm{~h})$ to 20 at.\% ( $22 \mathrm{~h}$ ) in the case of $0.1 \mathrm{M} \mathrm{KF}$ ).

A dramatic change is detected after $0.3 \mathrm{M} \mathrm{KF}$ treatments (Fig. 4d) due to the formation of small (c.a. size $=100 \mathrm{~nm}$ wide) cubic crystals. Importantly, crevices can be observed on the surface.

With the aim of comparison, results of EDX analysis after $1 \mathrm{~h}$ immersion period in the $0.01-0.3 \mathrm{M}$ KF concentration range are shown in Fig. 5. It can be noticed that the oxygen at.\% decreases when the concentration of KF solution increases while the amount of fluoride increases. Interestingly, a significant increase of $\mathrm{K}$ at.\% [from $0.05(0.1 \mathrm{M} \mathrm{KF})$ to $1.39(0.3 \mathrm{M})$ ] was detected. After a long exposure (7 days) of $\mathrm{Mg}(\mathrm{PM})$ to $0.1 \mathrm{M} \mathrm{KF}$ solutions the microstructural characteristics of the layer coating change and $\mathrm{KMgF}_{3}$ was identified by XRD analysis (not shown).

\subsection{The effect of $\mathrm{Cl}^{-}$-containing solutions on $\mathrm{F}$-CC}

\subsubsection{Transient current and $E_{\text {ocp }}$ measurements}

To test the change of the passivating characteristics of F-CC by chloride ions (the most aggressive among the anions of biological fluids) transient currents were recorded at $\mathrm{E}_{\mathrm{ocp}}+50 \mathrm{mV}$ with $\mathrm{Mg}$ (PM)SA. Firstly, very thin F-CCs were formed in chloride-free solution during 0.5 and 1 min respectively and subsequently chloride ions were added to the $\mathrm{F}^{-}$-containing medium. If the addition of chlorides is made after $1 \mathrm{~min}$ it can be noticed (Fig. 6) that the current initially decreases due to the passivating action of fluorides, then increases slowly and finally remains nearly constant. However, when the addition was made after $0.5 \mathrm{~min}$ the current increased sharply.

Similarly, $\mathrm{E}_{\text {ocp }}$ variation with time also showed different responses depending on the time at which the $\mathrm{NaCl}$ addition was made. Results obtained during $0.1 \mathrm{M} \mathrm{KF}$ treatments before and after the addition of $\mathrm{NaCl}$ up to physiological level $\left(8 \mathrm{~g} \mathrm{~L}^{-1}\right)$ are shown in Fig. 7. Initially, the $\mathrm{E}_{\text {ocp }}$ value increased sharply up to c.a. $-1.17 \mathrm{~V}$ and then remained nearly constant without change when the addition of $\mathrm{NaCl}$ was made after 1 min. Conversely, $E_{\text {ocp }}$ decreased abruptly and very unstable values were recorded when the addition was made 0.5 min after the beginning of the experiment.

\subsubsection{Electrochemical impedance spectroscopy (EIS)}

EIS experiments were performed with $\mathrm{Mg}(\mathrm{PM})$ electrodes previously treated in $\mathrm{KF}$ solutions $(0.01-03 \mathrm{M}$ concentration range) to make a comparative analysis of the protective characteristic of the FCCs. EIS was performed under $\mathrm{E}_{\text {ocp }}$ condition in $8 \mathrm{~g} \mathrm{~L}^{-1} \mathrm{NaCl}$. The impedance results are shown in both the Nyquist and the Bode plots in Fig. 8. The Nyquist diagrams (Fig. 8a, imaginary part $Z^{\prime \prime}$ vs. real part $Z^{\prime}$ ) show a semicircle, corresponding to the charge transfer resistance limiting process related to $\mathrm{F}-\mathrm{CC} / \mathrm{electrolyte}$ interface $\left(\mathrm{R}_{\mathrm{CT}}\right)$. Its intersection with the real axis, at high frequencies, corresponds to electrolyte resistance $\left(R_{e}\right)$. At low frequency an inductive behavior also appears.

The capacitance was calculated from experimental data as $C=1 /$ ( 2 $\pi f_{i} R_{T C}$ ). The frequency $f_{i}$ was selected to obtain a maximum value of $Z_{\mathrm{i}}$, where $Z_{\mathrm{i}}$ is the imaginary part of the impedance (Table 1 ).

The impedance modulus Bode diagrams (Fig. $8 \mathrm{~b}$ and c) revealed a plateau at high frequencies. The impedance value at this region, with $\varphi=0$ (Fig. 8c), gives the electrolyte resistance in each case. At decreasing frequencies $\left(10^{3} \mathrm{~Hz}-10 \mathrm{~Hz}\right)$ the slope can be attributed to one capacitor in parallel with a resistance corresponding to the $\mathrm{F}-\mathrm{CC} /$ electrolyte interface with a phase angle whose value is shown in Table 1 . In the lower frequency range, the phase angle is close to $0^{\circ}$, corresponding to a plateau in the impedance modulus vs. frequency plot. Thus, the total resistance of the circuit $\left(R_{e}+R_{C T}\right)$ can be obtained. The experimental results are shown in Table 1.

\subsubsection{EDX analysis and SEM of the F-CCS after immersion in $\mathrm{NaCl}$ solutions}

Fig. 5 shows that the F-content of the F-CC drastically decreases during the immersion in $\mathrm{NaCl}$ solution (compare $\mathrm{F}$ atomic percent before and after the immersion in the chloride solution $((\mathrm{F})$ and $(\mathrm{F}(\mathrm{Cl}$ sol)) respectively)). Additionally an important increase in the oxygen content can also be observed (Table 2).

The F-CCs are more vulnerable to chloride attack when the fluorides are absent in the solution (i.e. biological solutions). After $1 \mathrm{~h}$ exposure periods in $\mathrm{KF}$ followed by immersion in a fluoride-free $\mathrm{NaCl}$ solution for $1 \mathrm{~h}$, the $\mathrm{Mg}(\mathrm{PM})$ surface showed areas with corrosion products and localized attack (Fig. 9a) and other regions that remain protected (Fig. 9b). Fe and Si impurities detected by EDX seem to favor localized attack.

\section{Discussion}

The protective characteristics of F-CCs formed on $\mathrm{Mg}(\mathrm{PM})$ with $\mathrm{KF}$ solutions in the 0.01-03 $\mathrm{M}$ concentration range were evaluated comparatively. $\mathrm{Mg}(\mathrm{PM})$ samples with $\mathrm{F}-\mathrm{CC}$ s were subsequently immersed in a $8 \mathrm{~g} \mathrm{~L}^{-1} \mathrm{NaCl}$ solution to elucidate the effect of chloride on the degradation of F-CCs without the interference of other ions. Useful information to select an appropriate treatment to provide temporary protection to $\mathrm{Mg}(\mathrm{PM})$ in biological media could be obtained from the results.

Several corrosion studies of magnesium and magnesium alloy dissolution have been performed for industrial and medical applications. The overall corrosion mechanism accepted for neutral and alkaline media is [1-3]:

$\mathrm{Mg}+2 \mathrm{H}_{2} \mathrm{O} \leftrightarrow \mathrm{Mg}(\mathrm{OH})_{2}+\mathrm{H}_{2}$

With the following partial reactions:

$\mathrm{Mg} \leftrightarrow \mathrm{Mg}^{2+}+2 \mathrm{e}^{-}$

$2 \mathrm{H}_{2} \mathrm{O}+2 \mathrm{e}^{-} \leftrightarrow \mathrm{H}_{2}+2 \mathrm{OH}^{-}$

or

$2 \mathrm{H}^{+}+2 \mathrm{e}^{-} \leftrightarrow \mathrm{H}_{2}$ 

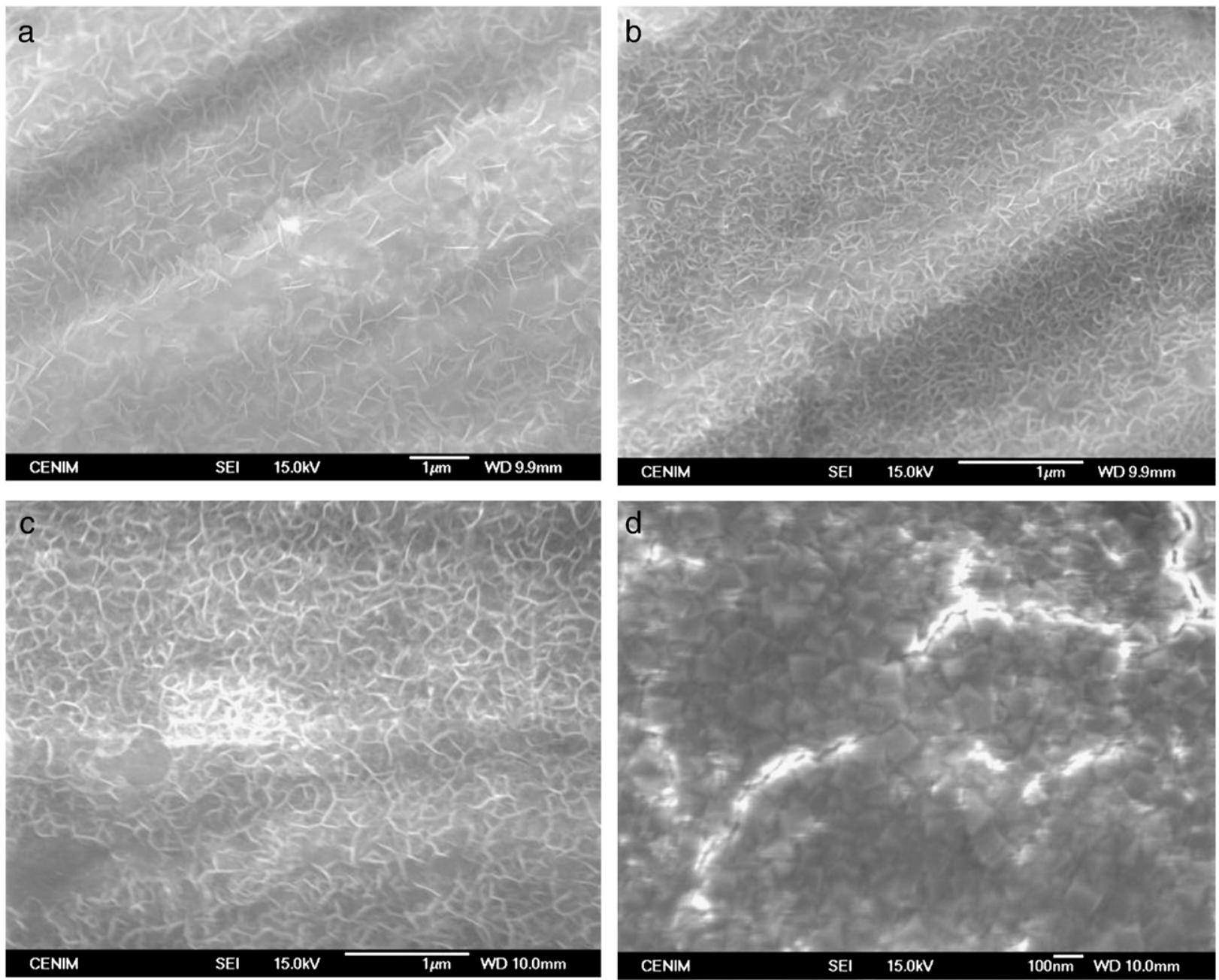

Fig. 4. SEM microphotographs of $\mathrm{Mg}(\mathrm{PM})$ after $1 \mathrm{~h}$ immersion in (a) $0.01 \mathrm{M}$; (b) $0.03 \mathrm{M}$; (c) $0.1 \mathrm{M}$ and (d) $0.3 \mathrm{M}$ KF. Cubic crystals and crevices can be distinguished in (d).

Alternately a one electron step followed by a chemical step was also proposed,

$\mathrm{Mg} \mathrm{Mg}^{1+}+1 \mathrm{e}^{-}$

$2 \mathrm{Mg}^{+}+2 \mathrm{H}_{2} \mathrm{O} \leftrightarrow 2 \mathrm{Mg}^{2+}+2 \mathrm{OH}^{-}+\mathrm{H}_{2}$ (chemical reaction).

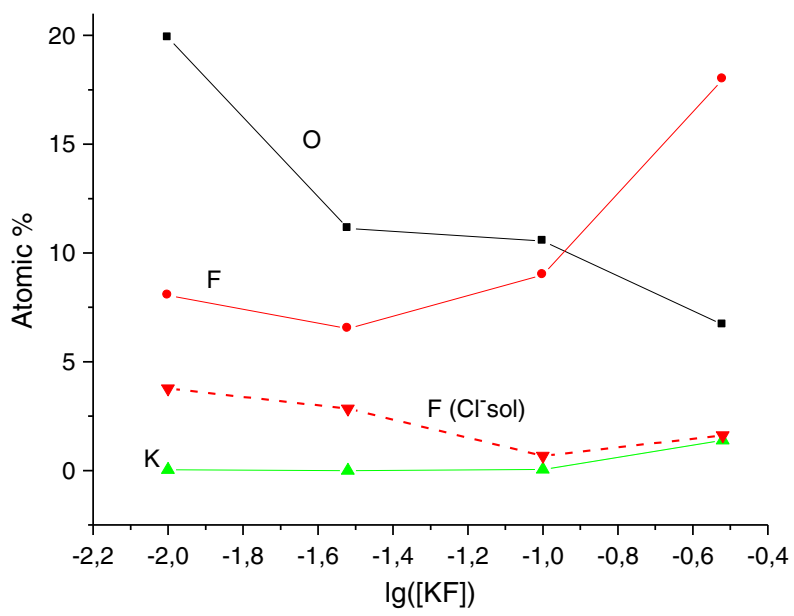

Fig. 5. Atomic percent of the elements (O, F, and $\mathrm{K}$ ) obtained by EDX analysis of F-CC formed with different $\mathrm{KF}$ concentrations $(0.01 \mathrm{M}, 0.03 \mathrm{M}, 0.1 \mathrm{M}$, and $0.3 \mathrm{M})(-) . \mathrm{F}^{-} \mathrm{Cl}^{-}$sol $)$corresponds to the atomic percent of $\mathrm{F}$ after the $\mathrm{F}-\mathrm{CC}-\mathrm{Mg}(\mathrm{PM})$ immersion in $8 \mathrm{~g} \mathrm{~L}^{-1} \mathrm{NaCl}(---)$.
Followed by

$\mathrm{Mg}^{2+}+2 \mathrm{OH}^{-} \leftrightarrow \mathrm{Mg}(\mathrm{OH})_{2}(\mathrm{~s})$.

The overall reaction consumes $\mathrm{H}^{+}$or produces $\mathrm{OH}^{-}$(Eqs. (3a) and (3b)), and consequently the $\mathrm{pH}$ increases and favors the formation of $\mathrm{Mg}(\mathrm{OH})_{2}$.

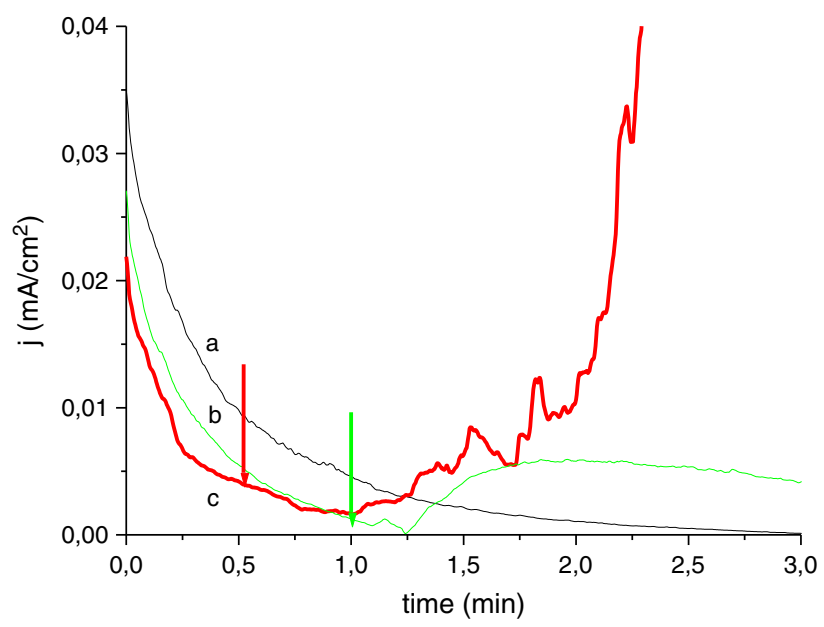

Fig. 6. Transient currents corresponding to $\mathrm{Mg}(\mathrm{PM}) \mathrm{SA}$, recorded at $50 \mathrm{mV}$ more anodic than the open circuit potential in $0.1 \mathrm{M} \mathrm{KF}$. (a) Control, (b) NaCl up to $8 \mathrm{~g} \mathrm{~L}^{-1}$ is added after $1 \mathrm{~min}$, and (c) after $0.5 \mathrm{~min}$. The addition of $\mathrm{NaCl}$ is indicated with the arrows. 


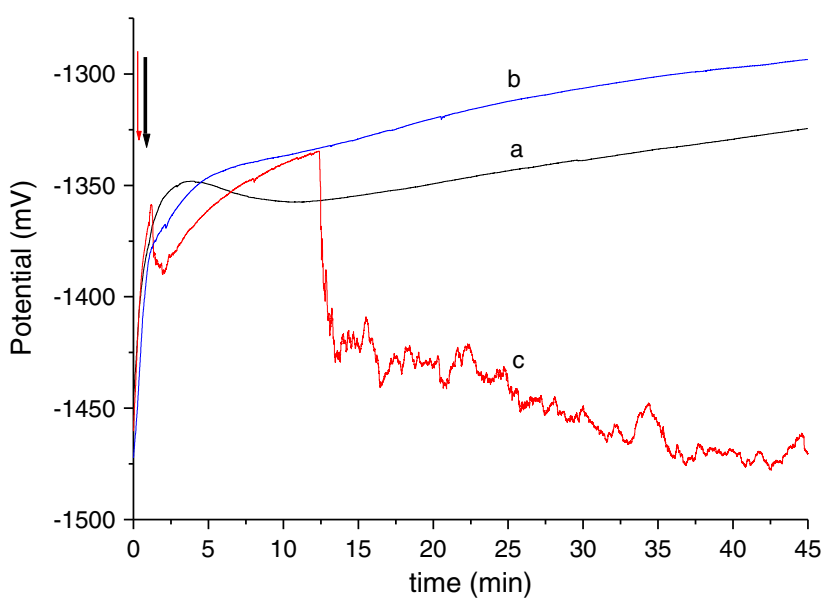

Fig. 7. $\mathrm{E}_{\mathrm{ocp}}$ Vs. time plot corresponding to $\mathrm{Mg}(\mathrm{PM}) \mathrm{SA}$ in $0.1 \mathrm{M} \mathrm{KF}$. (a) Control, (b) $\mathrm{NaCl}$ up to $8 \mathrm{~g} \mathrm{~L} \mathrm{~L}^{-1}$ is added after $1 \mathrm{~min}$, and (c) after $0.5 \mathrm{~min}$. The addition of $\mathrm{NaCl}$ is indicated with the arrows.

As $\mathrm{Mg}(\mathrm{OH})_{2}$ is a poor electron conductor this suggests that the $\mathrm{H}_{2}$ reaction may be occurring mainly in the pores at points at which are the shortest distance to the metal [43].

In the case of $\mathrm{Mg}(\mathrm{PM})$ the microstructure includes $\mathrm{MgO}$ particles that reinforce mechanical properties. These particles may also affect the corrosion behavior of $\mathrm{Mg}(\mathrm{PM})$ since electrochemical measurements show more anodic $\mathrm{E}_{\mathrm{ocp}}$ and lower current densities for pure $\mathrm{Mg}$ with $\mathrm{MgO}$ coating than for bare $\mathrm{Mg}$ [44].

SECM proved to be a sensitive localized technique able to evaluate the changes of the chemical activity of the $\mathrm{Mg}(\mathrm{PM}) \mathrm{SA}$ surface with time. It was revealed that the activity of spatially-confined sites can be sensed and that this reactivity decreases when the immersion time in $\mathrm{KF}$ solution increases. SECM results showed that the $\mathrm{Mg}(\mathrm{PM}) \mathrm{SA}$ surface, initially very active and showing scattering current values, is progressively passivated in the $0.1 \mathrm{M}$ KF solution, reaching low and constant current values that indicate the passive state of the sample. It seems that in aqueous fluoride-containing solutions the $\mathrm{Mg}(\mathrm{OH})_{2}$ film (slightly stable in water) reacts with fluorides and forms $\mathrm{F}^{-}$containing Mg compounds according to [45]:

$\mathrm{Mg}(\mathrm{OH})_{2}+\mathrm{xF}^{-} \rightarrow \mathrm{Mg}(\mathrm{OH})_{2-\mathrm{x}} \mathrm{F}_{\mathrm{x}}+\mathrm{xOH}^{-}$.

If $\mathrm{x}=2$

$\mathrm{Mg}(\mathrm{OH})_{2}+2 \mathrm{~F}^{-} \rightarrow \mathrm{MgF}_{2}+2 \mathrm{OH}^{-}$.

Additionally in the presence of $\mathrm{K}$ cations, and depending on the fluoride concentration, $\mathrm{MgKF}_{3}$ could also be obtained according to:

$\mathrm{Mg}(\mathrm{OH})_{2}+\mathrm{K}^{+}+3 \mathrm{~F}^{-} \rightarrow \mathrm{MgKF}_{3}+2 \mathrm{OH}^{-}$

or

$\mathrm{MgF}_{2}+\mathrm{KF} \rightarrow \mathrm{MgKF}_{3}$

The decrease of oxygen at.\% at the surface and the increase of fluor at.\% when the concentration of the KF solution increases as well as the increase in $\mathrm{K}$ content of the layer (Fig. 5) and the identification of $\mathrm{KMgF}_{3}$ for long immersion times are in agreement with this sequence of reactions.

According to SEM observations (Fig. 4d) F-CC formed with $0.3 \mathrm{M}$ $\mathrm{KF}$ revealed crevices where corrosion seems to be facilitated. These results are in agreement with those reported for AZ91D alloys [30].

The protective F-CCs can also be formed on corroded samples (Mg (PM)SA). Transient currents revealed that in the case of $0.3 \mathrm{M} \mathrm{KF}$ solution a less protective layer is formed.
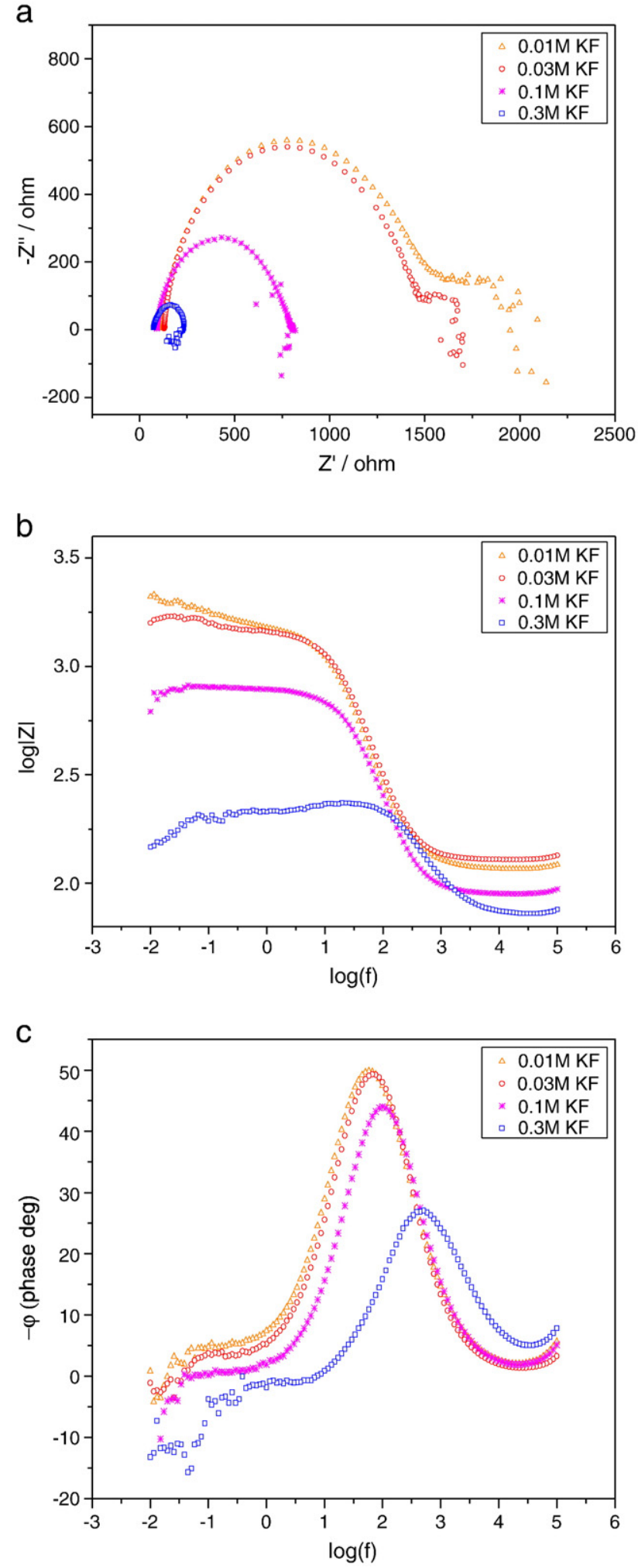

Fig. 8. EIS spectra of the (a) Nyquist and (b, c) Bode diagrams of $\mathrm{Mg}(\mathrm{PM})$ immersed in $8 \mathrm{~g} \mathrm{~L}^{-1} \mathrm{NaCl}$ after the following treatments for $1 \mathrm{~h}$ : $0.01 \mathrm{M}, 0.03 \mathrm{M}, 0.1 \mathrm{M}$ and $0.3 \mathrm{M} \mathrm{KF}$.

The impedance diagrams of $\mathrm{Mg}(\mathrm{PM})$, in $8 \mathrm{~g} \mathrm{~L}^{-1} \mathrm{NaCl}$ solution, after $1 \mathrm{~h}$ immersion pre-treatment in $0.03 \mathrm{M}, 0.01 \mathrm{M}, 0.1 \mathrm{M}$ and $0.3 \mathrm{M} \mathrm{KF}$ solutions, exhibit one capacitive loop. For simplicity one might take the real impedance at which the imaginary part vanishes for the capacitive part to be the charge transfer resistance $\mathrm{R}_{\mathrm{TC}}$ and relate it to the corrosion resistance. Therefore, the corrosion resistance $R_{C T}$ decreases from $1032.29 \Omega \mathrm{cm}^{2}$ to $144.18 \Omega \mathrm{cm}^{2}$ (close to that obtained in the absence 

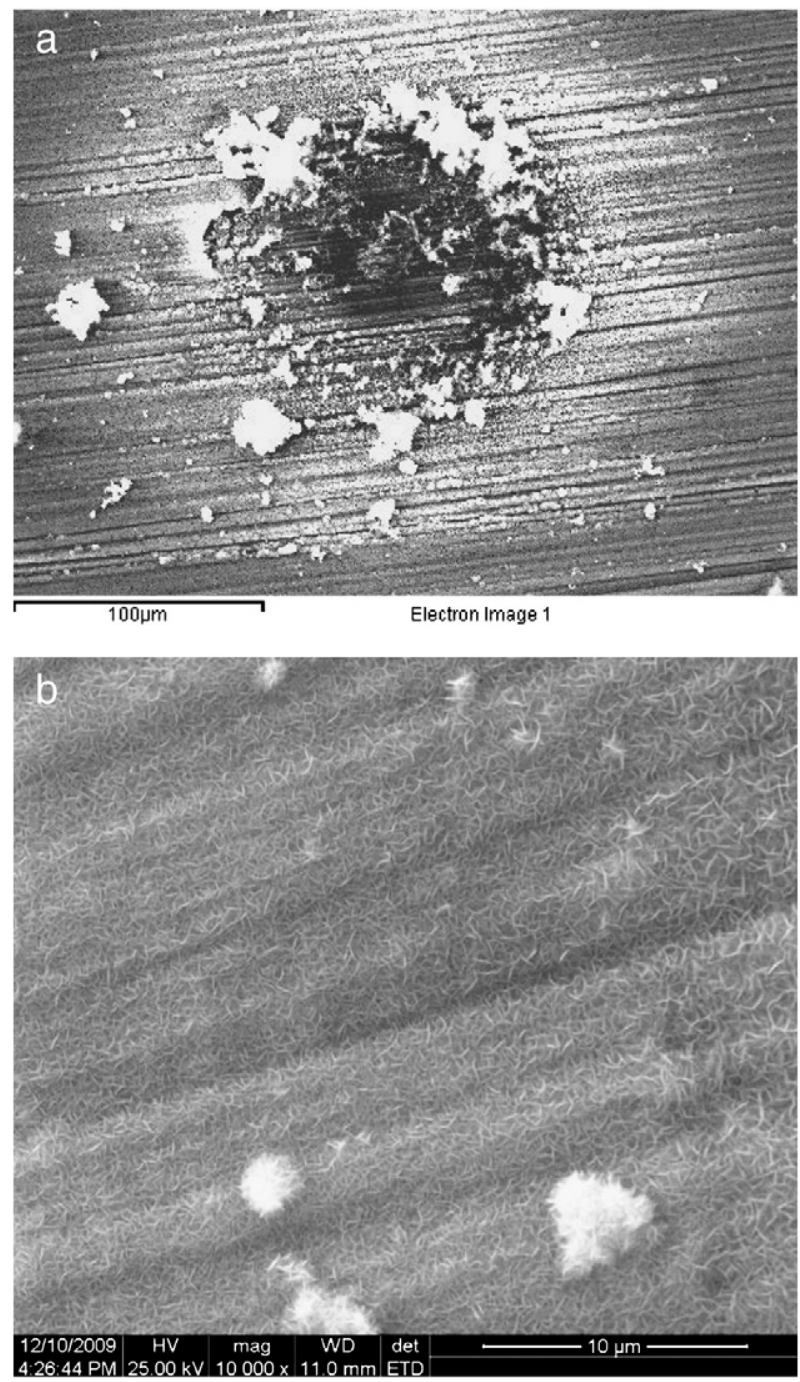

Fig. 9. SEM image of a $\mathrm{Mg}(\mathrm{PM})$ sample after immersion in $0.1 \mathrm{M} \mathrm{KF}$ solution for $1 \mathrm{~h}$ and then in a fluoride-free $8 \mathrm{~g} \mathrm{~L}^{-1} \mathrm{NaCl}$ solution for $1 \mathrm{~h}$. (a) Localized attack and corrosion products can be observed. (b) Region without attack.

of F-treatment [26]) when the concentration of the KF solution increases from $0.01 \mathrm{M}$ to $0.3 \mathrm{M}$. This behavior seems to reflect that, in the presence of $\mathrm{Cl}^{-}$, the charge transfer resistance, associated with the inhibitory effect of $\mathrm{F}^{-}$, decreases when the concentration of the KF in the pretreatment increases.

At low frequencies, an inductive behavior appears, more defined in the case of $0.01 \mathrm{M}$ and $0.03 \mathrm{M}$ solutions, usually associated to adsorption-desorption of ions in a corrosion process. Our results and those of Chiu [24,26] revealed that the composition and structural characteristics of the F-CC affect the degradation profile of this layer. SEM and EDX analysis revealed (Figs. 4 and 5) that the microstructural characteristics and composition of the F-CC change with the concentration of the $\mathrm{KF}$ solutions used. Crystallographic $\mathrm{KMgF}_{3}$ or more

Table 1

Experimental parameters obtained from EIS plots of $\mathrm{Mg}(\mathrm{PM})$ in $8 \mathrm{~g} \mathrm{~L}^{-1} \mathrm{NaCl}$ with pretreatments in KF solutions of different concentrations.

\begin{tabular}{lrrrrrl}
\hline $\mathrm{KF}$ & $\mathrm{E}_{\text {oc }}(\mathrm{V})$ & $\mathrm{R}_{\mathrm{e}}(\Omega)$ & $\mathrm{R}_{\mathrm{CT}}\left(\Omega \mathrm{cm}^{2}\right)$ & $\mathrm{C}\left(\mathrm{F} \mathrm{cm}^{-2}\right)$ & \multicolumn{1}{l}{$\mathrm{b}$} & $\varphi$ \\
\hline $0.3 \mathrm{M}$ & -1.620 & 72.55 & 144.18 & $4.8910^{-6}$ & -0.33 & -27.03 \\
$0.1 \mathrm{M}$ & -1.550 & 89.51 & 586.86 & $6.9910^{-6}$ & -0.52 & -41.41 \\
$0.03 \mathrm{M}$ & -1.570 & 128.53 & 1018.96 & $9.0810^{-6}$ & -0.63 & -49.31 \\
$0.01 \mathrm{M}$ & -1.560 & 116.69 & 1032.29 & $10.2610^{-6}$ & -0.64 & -49.83 \\
\hline
\end{tabular}

Table 2

EDX analysis of the samples with different F-CC (0.01-03 M KF) after immersion in $8 \mathrm{~g} \mathrm{~L}^{-}$ $\mathrm{NaCl}$ solution for $1 \mathrm{~h}$

\begin{tabular}{lcccc}
\hline Element/K $\alpha$ & $0.01 \mathrm{M} \mathrm{KF}$ & $0.03 \mathrm{M} \mathrm{KF}$ & $0.1 \mathrm{M} \mathrm{KF}$ & $0.3 \mathrm{M} \mathrm{KF}$ \\
\hline O K & 35.99 & 36.01 & 55.49 & 45.98 \\
F K & 3.77 & 2.84 & 0.67 & 1.61 \\
Mg K & 60.00 & 60.95 & 43.59 & 51.78 \\
P K & 0.00 & -0.01 & 0.04 & 0.02 \\
Cl K & 0.25 & 0.21 & 0.04 & 0.60 \\
\hline
\end{tabular}

amorphous $\mathrm{MgF}_{2}$, of different protective characteristics, can be obtained by varying the conditions of the pre-treatment [24].

Transient currents and $\mathrm{E}_{\text {ocp }}$ measurements (Figs. 6 and 7) also revealed interesting results in relation to the competitive action of chloride ions. These results indicate that the F-CC progressively achieves its protective characteristics in $\mathrm{F}^{-}$-containing solutions both in corroded and non corroded samples, in the absence of chloride ions. However, after the addition of chloride ions at the physiological level they show a very aggressive behavior competing with the fluoride ions of the solution and of the coating for the adsorption sites. Thus, the very labile F-CC formed after $0.5 \mathrm{~min}$ in $0.1 \mathrm{M} \mathrm{KF}$ solution can be easily attacked by chloride ions. After $1 \mathrm{~min}$ of immersion in the KF solution a more resistive behavior was shown, revealing the importance of the immersion time of fluoride treatments. Importantly, in fluoride-free $\mathrm{NaCl}$ solutions (like biological fluids) the F-content decreases drastically while oxygen-content increases. Consequently, the protective characteristics are progressively lost (Table 2 ) and localized attack can be observed after the $1 \mathrm{~h}$ immersion period (Fig. 9a).

The complex behavior of F-CC in chloride solutions could be explained considering: (a) the local change of $\mathrm{pH}$ and the high electron affinity of fluoride in the absence of chlorides and (b) the competition for the adsorption sites in the presence of chlorides $[30,43,45-47]$. Thus, there must be two successive processes occurring at the anodic interface. Firstly, the hydrolysis of the metal ions coming from the corrosion reaction and then the formation of $\mathrm{H}_{\mathrm{i}} \mathrm{F}_{\mathrm{i}+1}$ adsorbates due to the presence of $\mathrm{F}^{-}$(highly electronegative ions with strong binding energy with hydrogen ions) that protects the $\mathrm{Mg}(\mathrm{PM})$ surface. When chloride is present in the electrolyte media both, chloride and fluoride of the F-CC compete for the adsorption sites. Results showed that chloride ions induce the dissolution of $\mathrm{F}^{-}$containing products, since the F content of F-CC drastically decreases after the immersion in chloride solutions (Table 2, Fig. 5). Thus, the surface layer becomes more labile to the corrosion attack and oxygencontaining corrosion products are formed on the surface according to the increase of the $\mathrm{O}$ atomic percent of the layer detected by EDX (Table 2). In agreement, results also showed that chloride aggressive action is more effective when a thin, weak F-CC is formed, i.e., when a treatment with a short immersion period in the KF solution is applied (Fig. 6). Consequently, the comparative analysis of the data reveals that the composition, the structural characteristics and the corrosion resistance of the F-CC depend on the fluoride concentration and the immersion time of the solution. After the immersion in chloride solutions and in the absence of fluorides (like biological fluids) the corrosion resistance decreases due to the reduction of the F-content of the F-CC layer. This temporary protection of F-CC is appropriated for their application as biodegradable implants.

Accordingly, $\mathrm{Mg}(\mathrm{PM})$ with F-CC shows low corrosion rates initially and could originally preserve their mechanical integrity while the bone is healing. Subsequently a chloride assisted corrosion process could complete the degradation of the biomaterial. Importantly, it should be emphasized that an advantage of $\mathrm{Mg}(\mathrm{PM})$ with respect to $\mathrm{Mg}$ alloys is that its dissolution is not accompanied by the release of other less biocompatible metals.

Overall, results showed that SECM is a sensitive technique which enabled the evaluation of the progressive passivating action of fluoride 
on $\operatorname{Mg}(\mathrm{PM}) \mathrm{SA}$ in the absence of chloride ions. These results are in concordance with transient current measurements that revealed that the current decreases with time (except for $0.3 \mathrm{M} \mathrm{KF}$ treatment where crevices are formed). On the other hand, the variable protective behavior of F-CC in the presence of chloride ions at physiological level could be followed by EIS, $\mathrm{E}_{\text {ocp }}$ and transient current records. It was demonstrated that the F-CC progressively loses its corrosion resistance. The dissolution rate depends both on the immersion period and on the concentration of KF solution of the pre-treatment. High KF concentrations $(0.3 \mathrm{M})$ or short immersion times adversely affect the corrosion resistance of the layer in chloride solutions. Thus, the degradation profile of F-CC on $\mathrm{Mg}(\mathrm{PM})$ could be controlled to satisfy the implant requirements by the adequate selection of the concentration of the $\mathrm{KF}$ solution and of the immersion period of the inhibition treatment.

\section{Acknowledgements}

This work was financially supported by the Consejo Nacional de Investigaciones Científicas y Técnicas (CONICET) (PIP 6075), the Agencia Nacional de Promoción Científica y Técnica (PICT 0533225), the Universidad Nacional de La Plata (UNLP) (grant no: 11-I129), and by the grants CTQ2005-087-C02-01, CTQ2008-05775/BQU and MAT 2009-14452 (Ministerio de Educacion y Ciencia, Spain), by the grant AVANSENS S2009/PPQ-1642 (CAM) and by the SEM service of LIMF, Facultad de Ingeniería, UNLP.

\section{References}

[1] G. Song, A. Atrens, X. Wu, B. Zhang, Corros. Sci. 40 (1998) 1769-1791.

[2] G. Song, A. Atrens, M. Dargusch, Corros. Sci. 41 (1999) 249-273.

[3] J.E. Gray, B. Luan, J. Alloys. Compd. 336 (2002) 88-113.

[4] C.S. Wu, Z. Zhang, F.H. Cao, L.J. Zhang, J.Q. Zhang, C.N. Cao, Appl. Surf. Sci. 253 (2007) 3893-3898.

[5] L. Li, J. Gao, Y. Wang, Surf. Coat. Technol. 185 (2004) 92-98.

[6] F. Witte, V. Kaese, H. Haferkamp, E. Switzer, A. Meyer-Lindenberg, C.J. Wirth, H. Windhagen, Biomaterials 26 (2005) 3557-3563.

[7] F. Witte, J. Fisher, J. Nellesen, H.-A. Crostack, V. Kaese, A. Pisch, F. Beckmann, H. Windhagen, Biomaterials 27 (2006) 1013-1018.

[8] M.P. Staiger, A.M. Pietak, J. Huadmai, G. Dias, Biomaterials 27 (2006) 1728-1734

[9] S. Gruhl, F. Witte, J. Vogt, C. Vogt, J. Anal. At. Spectrom. 24 (2009) 117-248.

[10] B. Heubliein, R. Rohde, V. Kaese, M. Niemeyer, W. Hartung, A. Haverich, Heart 89 (2003) 651-656

[11] G. Mani, M.D. Feldman, D. Patel, C.M. Agrawal, Biomaterials 28 (2007) 1689-1710

[12] P. Zartner, R. Cesnjevar, H. Singer, M. Weyand, Catheterization and Cardiovascular Interventions 66 (2005) 590-594.

[13] G. Song, Corros. Sci. 49 (2007) 1696-1701.

[14] H. Inoue, K. Sugahara, A. Yamamoto, H. Tsubakino, Corros. Sci. 44 (2002) 603-610.
[15] L. Xu, E. Zhang, D. Yin, S. Zeng, K. Yang, J. Mater. Sci. Mater. Med. 19 (2008) 1017-1025.

[16] R. Retting, S. Virtanen, J. Biomed. Mater. Res. A 85 (2008) 167-175.

[17] Z. Li, X. Gu, S. Lou, Y. Zheng, Biomaterials 29 (2008) 1329-1344.

[18] R. Rettig, S. Virtanen, J. Biomed. Mater. Res. A 88 (2009) 359-369.

[19] W.-D. Mueller, M. Fernández Lorenzo de Mele, M.L. Nascimento, M. Zeddies, J. Biomed. Mater. Res. A 90 (2009) 487-495.

[20] X. Gu, Y. Zheng, Y. Cheng, S. Zhong, T. Xi, Biomaterials 30 (2009) 484-498.

[21] Y.F. Zheng, X.N. Gu, Y.L. Xi, D.L. Chai, Acta Biomater. 6 (2010) 1783-1791.

[22] X. Gu, W. Zhou, Y. Zheng, L. Dong, Y. Xi, D. Chai, Mater. Sci. Eng., C 30 (2010) 827-832.

[23] E.Y. Mgutmanas, Progr. Mater. Sci. 34 (1991) 261-366.

[24] M.D. Pereda, C. Alonso, L. Burgos-Asperilla, J.A. del Valle, O.A. Ruano, P. Perez, M.A. Fernández Lorenzo de Mele, Acta Biomater. 6 (2010) 1772-1782.

[25] P. Pérez, G. Garcés, J. Adeva, Mater. Sci. 42 (2007) 3969-3976.

[26] K.Y. Chiu, M.H. Wong, F.T. Cheng, H.C. Man, Surf. Coat. Technol. 202 (2007) 590-598.

[27] J.-Z. Li, J.-G. Huang, Y.-W. Tian, C.-S. Liu, Trans. Nonferrous Met. Soc. China 19 (2009) 50-54.

[28] S.F. Lamolle, M. Monjo, M. Rubert, H.J. Haugen, S.P. Lyngstadaas, J.E. Ellingsen, Biomaterials 30 (2009) 736-742.

[29] F. Witte, J. Fischer, J. Nellesen, C. Vogt, J. Vogt, T. Donath, F. Beckmann, Acta Biomater. 6 (2010) 1792-1799.

[30] F. El-Taib Heakal, A.M. Fekry, M.Z. Fatayerji, Electrochim. Acta 54 (2009) 1545-1557.

[31] A.J. Bard, M.V. Mirkin, in: A.J. Bard, M. Stratmann, P.R. Unwin, Dekker Marcel, B.R. Horrocks (Eds.), Encyclopedia of Electrochemistry, vol. 3, VCH, Weinheim, New York, 2003, p. 444,, 2003.

[32] A.J. Bard, Fu-Ren F. Fan, D.T. Pierce, P.R. Unwin, D.O. Wipf, F. Zhou, Science 254 (1991) 68-74.

[33] A.L. Barker, M. Gonsalves, J.V. Macpherson, C.J. Slevin, P.R. Unwin, Anal. Chim. Acta 385 (1999) 223-240.

[34] Y. Gonzalez-García, G.T. Burstein, S. Gonzalez, R.M. Souto, Electrochem. Commun. 6 (2004) 637-642.

[35] A.C. Bastos, A.M. Simoes, S. Gonzalez, Y. Gonzalez-Garcia, Electrochem. Commun. 6 (2004) 1212-1215, R.M

[36] C. Bragato, S. Daniele, M.A. Baldo, G. Denuault, Ann. Chim. 92 (2002) 3312-3323.

[37] D.O. Wipf, Colloid Surf. A Physicochem. Eng. Aspects 93 (1994) 251-261.

[38] C. Gabrielli, S. Joiret, M. Keddam, H. Perrot, N. Portail, P. Rousseau, V. Vivier, J. Electrochem. Soc. 153 (2006) B68-B74.

[39] J.C. Seegmiller, D. Buttry, J. Electrochem. Soc. 150 (2003) B413-B418.

[40] A.M. Simoës, D. Battocchi, D.E. Tallman, G.P. Bierwagen, Corros. Sci. 49 (2007) 3838-3849.

[41] X. Liu, Zhang Tao, Shao Yawei, Meng Guozhe, Wang Fuhui, Corros. Sci. 51 (2009) $1772-1779$.

[42] R. Rettig, S. Virtanen, J. Biomed Mat Res 85A (2007) 167-175.

[43] K.G. Cowan, J.A. Harrison, Electrochim. Acta 24 (1979) 301-308.

[44] Lei Ting, Ouyang Chun, Wei Tang, Lian-Feng Li, Le-Shan Zhou, Corros. Sci. 52 (2010) 3504-3508.

[45] S. Verdier, N. van der Laak, S. Delalande, J. Metson, F. Dalard, Appl. Surf. Sci. 235 (2004) 513-524.

[46] S.V. Lamaka, O.V. Karavai, A.C. Bastos, M.L. Zheludkevich, M.G.S. Ferreira, Electrochem. Commun. 10 (2008) 259-262.

[47] A. Yamamoto, T. Terawaki, H. Tsubakino, Mater. Trans. 49 (2008) 1042-1047. 